\title{
Old age in Byzantine society
}

\author{
CHRIS GILLEARD*
}

\begin{abstract}
This paper examines the status afforded old age in the Byzantine Empire. Frequently neglected in accounts of state formation or comparative history, this Christian imperial state transformed the moral ordering of the lifecourse. In contrast to both classical Greek and Roman society, old age acquired a distinct moral authority in Byzantine society. This status was not confined to a few members of the elite as in Sparta or Rome. The economic vulnerability, physical frailty and social marginality accompanying old age conferred an equal moral claim upon society that the state actively addressed. A mix of institutionalised and individual charities created a prototype 'welfare state' within which provision for old age played a significant part. Despite its neglect by most social historians of old age, the Byzantine Empire is of considerable historical significance in the development of the contemporary constructions of old age. Just as the Byzantine Empire helped erode the practice of slavery that had been widespread in the ancient Greek and Roman societies, so too did it help to create a prototype welfare state in which individual enterprise was tempered by a collective sense of inclusive Christian responsibility. The consideration extended by Byzantine society, to old age, to its weakness as well as to its wisdom and authority, instituted a step change from earlier classical traditions.
\end{abstract}

KEY WORDS - old age, Byzantine society, iconography, church and state, charitable institutions.

\section{Introduction}

Whilst old age in classical Greek and Roman society has been the subject of sustained academic interest (Richardson 1969; Finley 1984; Falkner I995; Cokayne 2003; Parkin 2003), little has been written about the position of old people and the expectations of old age in the state that succeeded them, the Byzantine Empire. ${ }^{1}$ At first glance, this is surprising since the Byzantine Empire survived much longer than either the earlier Hellenistic or Roman empires. ${ }^{2}$ Not only was it long lived, but it sustained a highly literate elite of civil servants and religious leaders that produced

* Centre for Behavioural and Social Sciences in Medicine, University College London. 
a relatively large body of literature compared with the relative illiteracy of Western Europe. Yet Byzantine social history remains a marginalised subject area and detailed information about the cultural and social aspects of everyday life in the Empire is limited. Though much has been written about the lives of the emperors, the everyday lives of the men and women who formed the Empire's citizenry have been only lightly sketched (cf. Charanis I973: especially 53-70; Jenkins i967; Kazhdan and Constable 1982). Particularly scant attention has been paid to the social organisation of the lifecourse and the transitions into and through adulthood. The present paper is an attempt to redress this dearth by considering the change in the status of old age that came about in Byzantine society.

Before turning directly to the topic of old age, it is worth considering why there has been a neglect of Byzantine social history and what implications this has for constructing a more general history of old age in western society. A number of factors have played a part. The demise of the Eastern Roman Empire and its cultural marginalisation after incorporation by the Ottoman Empire led to the perception that Byzantium could never be more than 'the immutable residue of Rome's decline' (Kazhdan and Epstein I990: xix). The Christian nations that eventually emerged in the West after the final collapse of the Roman Empire developed their own traditions and institutions with seemingly little reference to developments in the East. The ability of the western Church to survive and maintain a residual administrative structure throughout the 'dark ages' helped ensure the Christianisation of the West. Partly through its promulgation of the Crusades, the western Church gradually extended its claim to ownership of the Christian faith. After the sacking of Constantinople in $\mathrm{I} 453$, this claim was no longer disputed.

During the centuries following its political collapse, Byzantine society came to be seen as a kind of cultural and economic dead end, the impossible imperial union of Christian and classical traditions that eventually stultified intellectual and social progress ( $c f$. Arnason 2000: 45). This view was expressed most powerfully in Gibbon's monumental account of the fall of the Roman Empire (Gibbon I896). Though the Empire saw itself as the continuation of the [Christianised] Roman Empire, neither Emperors nor church leaders made any attempt to make Latin the dominant liturgical language. Greek was the lingua franca of the Empire, but even Greek was never imposed as the language of the church. Multi-ethnic, multi-lingual Byzantine society survived for so long in part because of its adaptability. Set against the 'light' governance exercised by the State, there was nevertheless an underlying and unchanging ideology oriented toward the universal truth of the Christian faith and the role of the 
Emperor as its guardian and protector on earth (Runciman 2003). This view of the Byzantine Empire as a society lightly governed yet ideologically imprisoned, alternately accommodating to and resisting change - whether from the rise of Islam in the East or the emerging nation states of western Europe - has led some to suggest that the Byzantine state was essentially on the 'wrong' side of history.

In consequence, the social, economic and cultural institutions established in Byzantine society have not been examined primarily as prototypes or forerunners of 'western society'. Rather they have been treated as mausoleums, as it were cultural 'cold stores' that preserved elements of a classical past that would be revitalised only after power had shifted decisively westwards. The limited scope of much contemporary writing - both literary and documentary - for this period, and the 'conservatism' of much Byzantine literature, means that there are few direct accounts of everyday life in Byzantium (Kazhdan and Epstein I990: xix-xx). It seems difficult to identify the cultural, economic and social elements of Byzantine society that served as precursors for the institutions of western society.

The salience given to the Orthodox schism within the history of the Christian Church and the tendency to view the Orthodox tradition as inevitably compromised by its subordination to the Ottoman caliphate has meant that Church history has all too often been the history of the church in the west ( $c f$. Hughes I979). Socially and economically, the late and incomplete emergence of feudalism as a dominant influence upon the economy of Byzantine society, relative to its more dynamic appearance in western Europe, has not fitted well into a Marxian account of social and state development (cf. Marx I965; Wickham I984; Rigby I998). The Byzantine Empire has been sequestered into the 'ancient' mode of production.

In short, modernity is seen as the evolution of the social, cultural and economic institutions that emerged in western Europe during the $5_{5}^{\text {th }}$ and $\mathrm{r} 6$ th centuries. Byzantine feudalism came too late, if it came at all, and could do too little to change the course of history (Kazhdan I993: IOo). In the end, it was western European society that provided the lasting bulwark against the Ottoman, and by extension oriental, incursion into 'Europe'. The Orthodox Church was rendered subordinate to the Ottoman Caliphate, and its direct influence on State and society rapidly faded from sight. From such a perspective, the Byzantine Empire served merely a holding function until the 'Christianised' West could emerge re-born, as the true inheritor of the civilising missions of Greece and Rome, preserving the continuity of European culture and society.

Such marginalisation is to be regretted, and is a very partial interpretation of the past. The Byzantine Empire formed a unique bridge between the world of classical antiquity and medieval society. It helped preserve 
much of the classical Greco-Roman tradition long after it had collapsed throughout western Europe. It built and sustained a distinctive culture, bringing together a mixture of Christian, classical and eastern traditions that has exercised a continuing influence over both West and East. It provided a model of sustained inter-ethnic tolerance which contrasts sharply with the intolerance manifested by its contemporary western neighbours. At its height, the Byzantine Empire surpassed in its material, intellectual and cultural riches all other states in Europe. For hundreds of years, it successfully held its own against the powerful Persian and Arab empires in the east and survived the various incursions of Bulgars, Goths, Normans and Slavs from the north and west. Alongside its military prowess, Byzantine society developed other institutional competencies whose focus was upon peace rather than war, consolidation rather than conquest. Most prominent was the extensive network of philanthropic institutions whose role in fashioning a Christian Europe has often been ignored.

This is one of Byzantium's most lasting legacies. Many of the institutions of Byzantine society were shaped by the early Christian church and it was through these institutions that societal protection was first organised and by which the moral values of life were most widely understood. Following Constantine's establishment of Christianity as the state religion in the fourth century $\mathrm{AD}$ and the subsequent division of the Roman Empire into eastern and western blocs, the Church became a central support in maintaining the imperial structure of society and in sustaining the position of the emperor. From $479 \mathrm{AD}$ onwards, the emperor received his crown from the Church. It was the Church that legitimated the emperor's rule as the continuation of the Roman Empire. By successfully integrating the administrative and military structures of the Roman Empire with the ideological underpinnings of the church, the Byzantine Empire succeeded in retaining much of the strength of the former Roman Empire whilst sustaining a diverse and disparate population within an expanding Christian community. In both Roman and Greek societies, little collective provision had been organised for the aged, for widows and orphans or for the sick and disabled. There were no 'classical' institutions that could serve as precursors of the modern 'welfare state'. But under the early influence of the Church's teachings, charitable provisions were made for all such groups within the Empire. Many were supported and some established by the Emperors themselves, and they were quickly imitated by other members of the nobility. These institutions were maintained in one form or another through all the perturbations of the Empire until its demise in the I5th century.

The Byzantine state integrated Christian institutions into classical society. It also preserved much of the European urban culture that the 
Greek and Roman empires had helped establish. After the fall of Rome, in 4IO AD, urban life in Western Europe collapsed and the population of Europe's major city declined from nearly 800,ooo in 300 AD to less than 40,00o by the end of the seventh century (Morrisson and Sodini 2002: I72). In contrast, Constantinople grew to become the largest, most cosmopolitan city of its time. Its 'streets resounded with a cacophony of Latin, Greek, and Syriac, Aramaic and Armenian, Coptic and Ethiopic, Gothic and Hunnic, Persian and Arabic' (Croke 2002: 74). Despite huge swings in fortune over the next seven centuries, Constantinople remained the emblematic 'world city' and sustained a rich and complex urban culture inherited from Greco-Roman 'classic tradition' but modified significantly through the growth of institutionalised Christianity. Throughout the Empire the principal institution that helped make sense of, and imposed order on, individual social life was the institutional Church. Its power was supported by and in turn supported the Emperor. Thus, the organisation and ideology of the Church and State came to define the organisation and ideology of the Empire itself.

The rest of this paper focuses on the ways by which the Church influenced the status of old age in Byzantine society, how it transformed the moral authority of the classical paterfamilias into the moral authority of old age, and how Church and State developed institutions that, for the first time in Europe, offered some degree of security against the vicissitudes of age, infirmity and illness. In doing so, it incorporated the poor, the weak and the disabled as both citizens of the State and subjects of the Emperor. In particular, the paper identifies three ways in which a new and distinct position was given to old age in Byzantine society. The first concerns the role of the State and the Church on family structure and the position of older people in the family, the second concerns the influence of Christian ideology on the moral status and authority of old age, and the third is the role of charitable institutions in the protection of those weakened by old age.

\section{Social and family life in Byzantine society}

Byzantine society remained polarised through most of its history. There existed a wealthy elite, made up of the imperial family and their officials, bishops and other senior figures in the Church, senior military officials and large land-owning families that held estates across several provinces (Mango I994: 39-44). At the other end of the scale were the poor, slaves, tenant farmers and unskilled workers, who lived their lives close to subsistence levels and under conditions of 'considerable insecurity' (Neville 2004: I67). The urban merchant class played a marginal role throughout much 
of this period and the growing amount of trade that was conducted by the state was largely mediated by foreigners residing in but not functioning as citizens of the Empire (Jenkins I967: 84-5), while the intelligentsia were largely incorporated into the imperial civil service or the Church.

For the majority of the population, life was short, hard and generally unrewarding. According to one writer, Byzantine life expectancy in the towns and cities was little more than 30 years, 'comparable with that of early Iron Age Greece' (Talbot 1984: 267). Laiou (2002) estimated life expectancy at birth to be as low as 23 years at the beginning of the 14 th century - although she acknowledged that it might have been higher in the Ioth to I2th centuries (2002: 52). This contrasts sharply with an estimate of life expectancy amongst the various Imperial families of just over 6o years. Life expectancy amongst clerics, monks and scholars may have been even higher (Kazhdan and Constable i982: i 7 ; Talbot I984). The life expectancy of most tenant and small freehold farmers is largely unknown and unknowable, but it seems likely that it was closer to that of the common people in cities than that of the elite. Patlagean's (I977) estimates for the fifth and sixth centuries suggest that fewer than I5 per cent of those wealthy enough to afford a funeral epitaph and who survived through their infancy and childhood died at or after the age of 65 years (1977: 99). Whatever the exact figures, the point is that most people did not live long enough to reach a venerable old age.

Under such circumstances, and given the endemic problems of war, disease and natural disasters that afflicted the Empire throughout its history, the majority of the population must have faced a constant struggle to maintain the viability of the family household. Widowhood and orphanhood were common experiences, while old age was realised more often amongst the rich and the clergy than amongst the general population. There was little support from the Church for re-marriage at any age, and this was particularly discouraged after 40 years-of-age. There was a clear expectation that children should look after their elderly parents, but with the important proviso that this was required only if the children were financially able to do so. For a minority amongst the well-to-do and for those who had chosen not to marry or have children, there was the option of retiring from 'family' life into a monastery. For the poor, institutions were established in many cities throughout the Empire, to care for the chronically sick, the disabled, the orphaned and infirm. Even if the number looked after in each particular institution was low, the network of such institutions seems to have been relatively extensive (Lascaratos, Kalantzis and Poulakou-Rebelakou 2004).

Regulations about family life were framed by the sixth-century Justinian Code, which remained the overarching legal framework of Byzantine 
society until well into the i2th century (Scheltema 1967: 65). One of the major shifts from Roman law that Justinian's codification achieved was the right for people to pass their wealth directly or indirectly to the Church, by requesting that it be distributed amongst the poor by the Church (MacCormack 1997: 663). This served as a brake on the accumulation of wealth in successful families, at least for much of the early years of the Empire. During the course of the ith century, 'a self-aware aristocracy' emerged which gradually weakened the power and control of the imperial system (Stephenson 2004: 187). Such elite families succeeded in developing an alternative power structure based upon strong kinship relations and underpinned by collective family possessions. Before this period, however, Byzantine families tended to be small, nuclear and consequently vulnerable.

From the earliest years of the Empire, the Church and State provided additional forms of support - whether through almsgiving, through the network of monasteries or through the various charitable institutions that flourished across much of the Empire. The creation of new forms of spiritual kinship as a viable alternative to biological kinship (Neville 2004: 87) led to a significant shift in the classical Roman tradition with its emphasis upon marriage and the biological tie between fathers and sons as the key link in society ( $c f$. Lassen 1997: II4). Authority relied less narrowly upon the 'patriarchy' of property, and extended to incorporate the spiritual power that age conferred.

A second change introduced by Justinian's laws was the formal acknowledgement of a woman's rights to become the head-of-household, provided she was the principal source of family income. As a result, widowhood did not automatically result in a status of economic dependency or poverty (ptôcheia) and many widows seem to have been able to survive successfully as heads-of-household without having to remarry (Morris 1976). These and other re-formulations of Roman law meant that the power of the head-of-household, the father of the family, was reduced from its level during the height of the Roman empire, as women's property rights and their legal protection increased (Kazhdan i998: Io). Dependence upon a husband was no longer an absolute necessity and women, if widowed early, need not remarry. The necessity of having many children to ensure 'security in old age' was also attenuated by the growth of the charitable institutions provided by Church and State, although in many of the rural areas such considerations (of alternative 'institutional' support) doubtless played a minor role. ${ }^{3}$

While detailed research into the family demographics of Byzantine society has not been extensive, such as there is suggests that most family households were quite small, with perhaps no more than four people 
sharing a property (Laiou-Thomadakis 1977). Large families seem to have been discouraged (Patlagean I977; Eyben 1980-8I), although as noted above this situation might have been quite different in the countryside. Much of the information concerning Byzantine household structure has derived from surviving state-tax cadasters (Litavrin 1990). The Byzantine state required regular information on household composition in order to maximise its income. This information was confined to the headof-household and the main heir[s] who it was presumed would take over responsibility for paying the household tax in the event of the death of the household head. There are no records of anyone's age. One inth-century list suggested that over half the households in a group of villages near Miletos were headed by widows or widowers. Around 40 per cent seem to have been headed by 'relatively young peasants' aged in the thirties (Litavrin I990). Such evidence does support the idea that multi-generation households were rare and that few couples survived to face old age together; but the evidence is limited.

Within the household, parents maintained relatively distant relationships with their children - more so than in the classical period. According to Mango, 'no sentimentality was to be lavished on children, who had to be purged from the start of the sin of vanity', and encouraged to model themselves upon 'the gravity of an old man - puer senex' (Mango I994: 227). The bond between the generations was weaker and there was considerable inter-generational social mobility in both the countryside and the cities. The ties of home and land were weaker in the Eastern Empire than in the 'feudal' West (Lefort I993), and the spread of monasticism encouraged the growth of institutional structures as 'alternatives' to the ties of biological kinship (Talbot 1990). The value placed by the church on sanctity and asceticism also militated against close bonds between parents and children, although it is difficult to know exactly how influential the teachings of the church were in reducing the importance of intergenerational relationships. Nevertheless, what does seem to have characterised Byzantine society was the demotion of childhood, youth and 'reproductive fitness' - as if the Church viewed the earlier stages of life as little more than rehearsals for a worthy old age that served as a crucial preparation for the passage into the next life. ${ }^{4}$ What is certainly the case is that wealth was no longer automatically transmitted down the generations as in classical times. Older couples and widows were encouraged to transfer their wealth instead to the Church and its institutions, which took on a wider role in the redistribution of wealth within society.

Elderly members of families - meaning those too old to work - were expected to be treated well and looked after by their children. But the expectation that families would 'look after their own' was conditional 
upon their resources. The provisions for the aged-poor indicate that many landlords - bishops and senior churchmen as well as secular notables assumed some 'seigniorial' responsibility for those without means. Since the earliest old-age homes were imperial foundations, the extension of such charitable support must have reflected the Byzantine view that the Emperor as well as those seeking to act as his representatives were 'fathers' to all. In wealthy households, access to resources in later life was easier. Many well-off older people had the opportunity to retire into a monastery. In some cases the rich established a monastery or retirement home for their own benefit so that, should they or their kin become unable to look after themselves, there would be somewhere to live and servants to look after them - whilst also performing the good deed of founding the institution in the first place. It was not uncommon for groups of relatives to found a monastery, into which they and their kin could move following widowhood or simply as a form of retirement. Such foundations also included a continuing provision to house a few aged poor (Lascaratos, Kalantzis and Poulakou-Rebelakou 2004). In other cases husbands and wives elected, late in their lives, to go into adjacent monasteries presumably to keep in touch while living out a more spiritually-focused later life (Talbot I990: I22).

By encouraging celibacy, discouraging re-marriage, de-emphasising the production and raising of children, and promoting entry into monastic life, the Church played an important role in constraining the power of the family (oikia) as compared with its position in Greek and Roman society. This pattern began to change after the inth century, as a number of authors have pointed out, when Byzantine society underwent a kind of 'feudalisation' ( $c f$. Kazhdan and Epstein I99o; Stephenson 2004). While writers disagree on the extent of this change, and in their interpretations, it seems clear that the imperialistic, Church-dominated, charitable Byzantine society of the early centuries (400-IOoo AD), during the 'high' middle ages underwent a transformation, one consequence of which was a rise in the importance of 'family' and family ties in securing economic and personal social security.

\section{Age and authority}

As already indicated, at the outset of the Empire, the Roman paterfamilias represented the traditional figure of male authority, with the power of life and death over his family. Although the power exercised by the father remained, it was later muted as the Byzantine Church placed less emphasis upon paternal familial power and indeed on the family as a whole 
(cf. Patlagean 1977). This Byzantine model of imperial and ecclesiastical paternalism did nothing to reduce the authority of age, however, and in many ways Byzantine society placed more respect upon age than Roman society. Age itself was an important source of spiritual capital. Images of the saints and other religious figures frequently emphasised their agedness; even Jesus was portrayed as an old man (see Dagron I991: 28). ${ }^{5}$ Part of this veneration of age might be attributed to the relative scarcity of old people in Byzantine society and their over-representation in the Church and in the imperial family, but much had to do with the way that age had become an indicator of moral worth (see Burrow ig88: 95ff. for a brief account of the concept aetas spritualis [spiritual age], the idealisation of senectus venerabilis [venerable old age] and the early Christian conflation of virtuous existence and life in old age as in aetas senectutus vita immaculata [a spotless life is old age]).

Most of the figures of authority in Byzantine society were or were meant to appear as seniors - whether abbots or bishops, counsellors or senators. Bishops and abbots once appointed retained their power and authority for the rest of their life. Women had to be aged 6o years before they could be appointed deaconesses, although this was later lowered to 50 years by Justinian (Clark I994: 88-9). In the church, the moral and spiritual worth attributed to old people was a function of their retaining doctrinal authority as well as their assumed freedom from carnal desire and proximity to the life to come. The virtue attributed to elderly church leaders gave age an authority that was based not upon the material power of the Roman father (patria potestas) but on the spiritual power of God and the relative distance from desire that age embodied. Youth, by comparison, with its diverse and undisciplined interests, had a more marginal status (cf. Cameron i979: i5).

As the role of the church grew within the state, religious imagery became a pervasive feature of everyday life. The veneration of age was especially salient in the iconic tradition. Talbot (1984: 273) described a painters' manual that dominantly portrayed saints and other holy men as 'grey or white haired and usually bearded figures'. Gone were the Hellenistic statues and portraits of beautiful youth. The instillation of spiritual values led to the representation of the imperial order as akin to that of the kingdom of God, the Emperor at its pinnacle and, below him, a hierarchy of bishops, notables and attendants, thin figures of stillness each with stern and stylised faces ( $f f$. Maguire $1989: 227-8$ ). No signs of motion, no muscular nakedness and, more often than not, no signs of youth to disrupt this divinely-appointed order.

The reverence for and power attributed to the painted image - the icon - is one of the most widely acknowledged features of Byzantine 
culture (Cormack 2000). The attitude of awe toward what we now see as highly stylised portraits has been a source of surprise to many, because it contrasts markedly with the way in which these portraits are now regarded. Grigg (1987) argued that the Byzantines ascribed much credulity toward these paintings and images because they were seen as 'second order images' derived from originals thought to have been made at the very birth of Christianity. Rather than acknowledging the 'artistry' of the painter, viewers chose instead to believe that the original models, from which the artists drew their inspiration, were direct and faithful representations of saints and apostles as they were in life. In other words, the 'realism' attributed to religious paintings was based upon a belief that the image was itself both sign and signifier of the reality, and hence the presence of the figure. Painted images acquired a holy status, since icons preserved the qualities of the figure that had been painted; and agedness was pervasively represented in these images.

Such attributions led to a backlash. The growth of religious institutions and images threatened to overwhelm the powers of the State. Triggered by the rise of Islam and its prohibitions over representational art, and mindful of the growing power of the iconodules (image worshipers), Leo III issued an edict in 730 that ordered the destruction of all religious icons (Norwich I998: I I-2). For more than a century, conflicts continued over the status of icons, but when peace was finally restored, the authority of the image and the authoritative influence of the age portrayed in those images were if anything enhanced. Secular and sacred powers were increasingly elided. The image used to represent the power of God was also an image of the power of the Emperor (Maguire ig89). Images of aged, grey-bearded figures 'crowning' the ruler or conferring appointments on younger figures duplicated the image of the patriarch conferring divine authority by crowning the emperor. ${ }^{6}$ Images of the sacred combined with images of age to reinforce the authority of the father, both in its Roman sense as patria potestas, and in its newer Christian sense as omnipotens Deus.

\section{Age and infirmity}

Old age was by no means always associated with power and authority, but even when age, infirmity and poverty came together, Byzantine society still extended its concern if not respect for age. As well as by its iconographies of power, Byzantine society was distinguished by its charitable institutions. From its origins in older Judaic traditions, the early Christian Church played an important role in organising the redistribution of wealth 
from the better off to the poor and wretched. Once established as the new state religion, this role was institutionalised. The new religious concern for the poor served secular as well as religious purposes, obtaining for the Church a privileged position of exemption from taxation. So it was able to accrue considerable material wealth, which was widely used both to serve the poor and to secure material and spiritual authority for its officers. Despite these mixed motives, the Church's teaching on the moral worth of poverty and the value of asceticism helped change attitudes toward the poor while contributing to its own successful incorporation into the state (Runciman 2004).

The philanthropic traditions of Byzantine society are evident from the period of Constantine (Constantelos I968: ix-xi; I99I). Among the most remarkable institutions of Byzantine society were the hospitals, poor houses, orphanages and old people's homes that were established by the various emperors, bishops, abbots and aristocratic families from the late fourth century. One of the earliest such charitable institution, if not the very first, was the poor house (ptôchotropheion) or rest home (katagôgion) established by Basil, Bishop of Caesarea in 370 CE. The Basileias, as it came to be known, "provided charitable care in six main areas: the poor, strangers and homeless, orphans, the elderly and infirm, lepers and the sick' (Crislip 2005: I05-6). Crislip has not been alone in arguing the uniqueness of Byzantine charitable foundations. According to Miller (I984), ' [no] sources refer to permanent charitable foundations of any kind before the fourth century of the Christian era [and] classical Greco-Roman society ... had no permanent institutions to relieve the misery of the very poor. By the end of the fourth century, philanthropic institutions were built that had an even more defined role in tending the sick and infirm' (1984: 54). The forerunner of the modern hospital, the first xenones were built in what is now Antakya, in south-east Turkey. They employed nursing and medical staff to care for the sick as well as to accommodate strangers (Horden 2005).

Many of these charitable institutions were established outside cities and large towns, where there were bishops and aristocratic families prepared to fund them, and also plentiful sick and poor people to occupy their beds. Hospitals were attached to large monasteries, partly to minister to sick and infirm monks, and partly to provide care to the surrounding populace. At a relatively early stage in their formation, both coenobitic and laura monastic systems developed services for the needs of their ageing members, which spawned variously infirmary areas, special dietary regimes and medical care. As these services became more and more comprehensive, the effect was to give monastics 'perhaps the best quality of elderly life in the ancient world' (Crislip 2005: I36). 
These Byzantine institutions, though founded with charitable motives, do not seem to have become the squalid poor-law institutions of latemedieval Western Europe. In the first place they had much clearer institutional differentiation, with separate foundations of orphanages, general and specialist hospitals, old people's homes, poor houses and hostels, each built to serve a distinct 'care group'. In these institutions, both religious as well as lay personnel oversaw the care provided. In many of the hospitals and infirmaries, municipal physicians (archiatrol) conducted daily rounds under the overall administrative rule of the priests or deacons. They in turn were assisted by nurses (hypourgoi) and various care-workers, cleaners and cooks (hyperetai). One account describes the provision of clean bedding and clothes for the inmates under the general supervision of deacons and deaconesses (Horden 2005).

Although it is clear that the infirmaries and hospitals included provision for the aged and infirm, distinct old-age hostels (gerokomeia) were established as separate institutions, attached to monasteries and churches. Some of the earliest 'residential homes for the aged' were separate, and some were converted mansions of wealthy aristocrats who had made over their residence for such charitable purposes (Constantelos ig68: 223-4). Many such institutions were established in towns and cities across the Empire throughout the Byzantine period. In one case, the Emperor, Leon VI (886-9I2) 'expelled the occupants of a brothel of Constantinople in the district of Kyphes and converted the building into a home for the aged' (Lascaratos, Kalantzis and Poulakou-Rebelakou 2004). Such was the enthusiasm for founding gerokomeia that, during the Ioth century, the Emperor passed an edict, later rescinded, that forbad any new buildings (Talbot I984: 278).

Not only do there seem to have been many such institutions but the care that they offered appears to have been of a remarkably high standard, as compared with that provided in medieval Western Europe. In one institution that accommodated 24 frail, aged persons, care was provided by six male nurses who were to ensure that the residents had a light but nourishing diet of olive oil, wine, bread and cheese, that they had sufficient wood for fuel, and that they received an appropriate 'allowance' for their clothing and other expenses. The regimes formalised by the typikon provided regular baths and clean bedding, and if one of the residents became ill, they were transferred to the adjoining hospital, where they received treatment from the attending physicians. A senior monk in overall charge was supported by a priest and chanter to address all the spiritual needs of the residents (Lascaratos, Kalantzis and Poulakou-Rebelakou. 2004).

In addition to the institutional provisions for frail older people, Byzantine medicine established its own tradition of 'geriatric' medicine, 


\section{${ }_{63} 6 \quad$ Chris Gilleard}

and several treatises were written on the diseases of extreme old age (eschatogeri) and the appropriate medical and dietary regimes for maintaining health and wellbeing in later life (Lascaratos and PoulakouRebelakou 200o). Brittle bones, poor memory, falls and immobility, failing sight, cataracts and hearing loss were all faithfully recorded, with frequent references to the lives of the rich and famous to illustrate these maladies of old age. Byzantine medical practice included various interventions to reduce the signs of old age, with remedies for hair loss, hair dyes, unguents for removing wrinkles, and creams for disguising 'age spots' and bruising (Lascaratos et al. 2004). Whilst 'geriatric care' was relatively well ordered for the benefit of the poor, as evidenced by the rules laid down in the typika of the gerokomeia, there was also a market for 'antiageing' products. Clearly some of the Byzantine elite were reluctant to embrace the humility of age. Their desire to distance themselves from old age did not go unattended by personal physicians, despite the official position that made old age 'an obligatory state' ordained by God and nature. ${ }^{7}$

\section{Discussion and conclusions}

Ever since Edward Gibbon's monumental work on the decline of the Roman Empire, modern histories of Byzantium have tended to focus on the Emperors who ruled or misruled the state, the battles and alliances they conducted with neighbouring states, and the gradual erosion of Imperial rule, culminating in the fall of Constantinople (Norwich I998; Ostrogorsky I968; Treadgold 200I). One consequence of the emphasis on 'decline and fall' has been to make Byzantine history seem exotic and irrelevant to the development of the modern state ( $c f$. Anderson 1975: 275; Szucs I988). This has not been helped by the dearth of documents or other sources concerning life outside the imperial circles and the Church. The social history of everyday life in the Empire has been difficult to construct, which makes any history of old age a particularly intractable and even dubious undertaking.

Nevertheless, features of Byzantine society are of great interest because they exerted a significant influence in changing the way old age was represented and understood in society. In Byzantium, old age became a much less marginalised stage of life than had been the case in either ancient Greek or even Roman society. ${ }^{8}$ The first and possibly most important feature was the institutional power of the Christian Church, a power achieved in large part by the foundation of extensive charitable institutions such as the nosokomeia, ptochotropheia and gerokomeia. These 
institutions created positions of influence and a new class of workers whose positions were dependent upon the abbots, bishops and other religious and secular leaders who founded and funded the establishments at which they worked. As Horden noted, despite their wealth, some of the most powerful elites in Byzantine society were exempted from the burdens of taxation. This was most notably the case for members of the institutionalised Church. To enable the Church to justify its privileged economic position, its leaders 'needed a highly visible symbol of how they were deploying the wealth generated not only through the[ir] immunities but also through the patronage of emperors and the ... donations of ordinary citizens' (Horden 2005: 363). The founding of hospitals, poor houses and old-age homes served that purpose, and remained a successful strategy whereby the poor were incorporated as deserving citizens - not people marginal to society but individuals that shared in and helped to define the universal citizenship that they enjoyed through Christ (and under his earthly representatives, the Emperor and his bishops). The aged infirm and the aged poor were necessary to justify the privileged position of the Church. They were not to be marginalised.

The second element was the change in the way that authority was represented in Byzantine society. To a large extent, the Eastern Empire drew its Imperial identity more from the powers of Christ than from its status as the continuation of Roman imperial power. Despite the interminable doctrinal disputes, these roots and the legitimation of the Church made the Empire fundamentally a conservative society, with an outlook that was heavily influenced by a belief in the imminence of the second coming and the illusory nature of human happiness and fulfilment (Mango I994: 20I ff.). Such conservatism was reinforced by the deadening influence of the classical tradition, which continued to determine much of the Empire's secular intellectual framework. Medical treatises repeatedly harked back to ancient Greek sources, as did Byzantine works of geography and history, while the system of primary and secondary education remained largely unchanged from that operating hundreds of years earlier in imperial Greece (Kazhdan and Epstein I990: I2I, I68).

Although attempts to integrate classical and Christian culture involved some intellectual challenges, as did the struggle to define the eternal truth embodied by Christ and revealed in his teachings, the energy devoted to these debates was directed less toward change than to stability. External pressures moved the state forward more than these internal disputes. The growing military and political power of Islam and of western Europe forced the Empire to seek alliances with strangers, to modify its military organisation and tax-raising powers, to develop its economy and its trading 
relationships, and actively to engage with and challenge the ideologies espoused by the Latin Church and the Islamic empire. But the impact of these external forces was always limited, while the overt preservation of the classical tradition was not accompanied by any comprehension of its inner 'spirit' (Mango I994: 255).

In a society that was based upon divinely-inspired, immutable imperial authority, and supported by an elite of the military, the landed nobility and an ecclesiastical aristocracy, power accumulated with age and tenure of office and property. Grey-haired, bearded figures dominate Byzantine iconography, and even the figure of Christ could be portrayed as an old man. Despite the relatively high literacy, the diversion of the Hellenistic tradition toward anthologies, commentaries and compendia and the pervasive hagiography meant that literature reinforced rather than challenged received wisdom. ${ }^{9}$ What radical wit remained was used to shore up rather than confront orthodoxy. Age was a sign of power, because it represented an unchanging, orthodox wisdom. In a society oriented toward the sombre and serious and that was mistrustful of dance, drama, games and music, and critical of all forms of passion beyond those expressed through suffering, older people exemplified the virtues that Byzantine society formally espoused.

Looked at this way, the sympathy evinced for those who suffered and the distrust of bodily desires and material interests gave the Byzantine state a strong rationale for exercising its power through charity. Charitable donations and foundations helped to balance individual wealth with collective responsibility. Just as the Byzantine Empire facilitated the erosion of slavery that had been widespread in the ancient Greek and Roman societies, so too did it help create a prototype welfare state in which individual enterprise was tempered by a collective sense of inclusive Christian responsibility. The consideration extended to old age, to its weaknesses as well as to its wisdom and authority, and distinguished Byzantine society as the enabler of a step change from the earlier classical traditions and forms.

\section{NOTES}

I In a recent survey of 'the long history of old age', there is no reference to the position of old people in the Byzantine Empire (Thane 2005), a situation unchanged from earlier historical reviews of old age ( $c f$. Minois 1989; Cole 1993; Johnson and Thane I998).

2 'The Byzantine Empire, as defined by the majority of historians, is said to have come into being when the city of Constantinople was founded in $324 \mathrm{AD}$ and ended when that same city fell to the Ottoman Turks in I453' (Mango I994: I). The focus of this 
paper is on the first 600 years from Constantine's conversion to Christianity up to the IIth century (and the Third and Fourth Crusades).

3 Some writers have suggested that small-holders were the predominant social class throughout the Byzantine period, but with no more than four people occupying each farmstead (Lefort I993: I08). Such small-holder families appear to have relied more upon neighbours than extended kin. Rather than having a strong long-standing relationship to the land, there was considerable rural mobility in the Eastern Empire, particularly among the peasant farmers (I993: iाo).

4 This is reflected in the early Christians' rejection of portraying Jesus as a handsome young man; he was in life ugly, acquiring beauty only after his transfiguration. Equally he was portrayed as child, adult and old man, signifying his encompassment of time itself (Dagron I991 : 28-9).

5 See the face of Christ as represented on the gold solidus of Justinian II, reproduced in Cormack (2000: 79).

6 See the inth century images of Samuel and David reproduced in Anderson (1978); and that of Otto II crowned by a bearded and aged Christ, reproduced in Maguire (1989).

7 Even in late-antiquity, some doctors still had the status of household slaves, maintained by the wealthy as a human first-aid kit. Significant numbers amongst the 'Hellenistic' elites of the Eastern Roman Empire still clung to the old, pre-Christian mores and no doubt continued to enjoy the fun, games and indulgencies of that period. Despite advancing years, some of secular-minded citizens still wished to be participants in the old cultures of excess (see the accounts of the lives of the Byzantine emperors of the ioth and ith centuries in Psellus i996).

8 In a review of old age in Roman society, it has been concluded that "there is nothing to indicate any significantly positive role for "the elderly" as a group in the Roman world. ... The feeling was ... that old age was a time not of power or authority but of acceptance ... and when necessary of withdrawal' (Parkin 2003: 275-6). Garland (1990: 286) said of Athenian society, "the conspicuous failure ... to address the problems facing the elderly is arguably a reflection of its pragmatic and unsentimental judgement upon the marginality and essential worthlessness of this age group for society'.

9 See the account of traditionalism in Byzantine prose literature by Ehrhard (translation 200I).

\section{References}

Anderson, J. C. 1978. Cod. Vat. Gr. 463 and an eleventh century Byzantine painting center. Dumbarton Oaks Papers, 32, I75, I77-96.

Anderson, P. 1975. Passages from Antiquity to Feudalism. New Left Books, London.

Arnason, J. 2000. Approaching Byzantium: identity, predicament and afterlife. Thesis Eleven, 62, 39-69.

Burrow, J. A. i988. The Ages of Man. Oxford University Press, Oxford.

Cameron, A. I979. Images of authority: elites and icons in late sixth century Byzantium. Past and Present, 84, 3-35.

Charanis, P. 1973. Social, Economic and Political Life in the Byzantine Empire, Variorum Reprints, London.

Clark, G. 1994. Women in Late Antiquity: Pagan and Christian Lifestyles. Oxford University Press, Oxford.

Cokayne, K. 2003. Experiencing Old Age in Ancient Rome. Routledge, London.

Cole, T. R. 1993. The Journey of Life: A Cultural History of Aging in America. Cambridge University Press, Cambridge. 
Constantelos, D. J. ig68. Byzantine Philanthropy and Social Welfare. Rutgers University Press, New Brunswick, New Jersey.

Constantelos, D. J. I991. Byzantine Philanthropy and Social Welfare. Second revised edition, Aristide D. Caratzas, New Rochelle, New York.

Cormack, R. 2000. Byzantine Art. Oxford University Press, Oxford.

Crislip, A. T. 2005. From Monastery to Hospital: Christian Monasticism and the Transformation of Healthcare in Late Antiquity. University of Michigan Press, Ann Arbor, Michigan.

Croke, B. 2002. Justinian's Constantinople. In Maas, M. (ed.), The Cambridge Companion to the Age of Justinian. Cambridge University Press, Cambridge, 6o-86.

Daley, B. E. I999. Building a new city: the Cappadocian fathers and the rhetoric of philanthropy. Fournal of Early Christian Studies, 7, 432-3.

Dagron, G. I99. Holy images and likeness. Dumbarton Oaks Papers, 45, 23-33.

Dölger, F. I967. Byzantine literature. In Hussey, J. M. (ed.), The Cambridge Medieval History: Volume IV, The Byzantine Empire: Part II Government, Church and Civilisation. Cambridge University Press, Cambridge, 207-64.

Ehrhard, E. 1897/2001. Prose literature: theology. In Krumbacher, K. (ed.), Geschichte der byzantinischen litteratur von Fustinian bis zum ende des Oströmischen reiches (527-I453) [The History of Byzantine Literature: From Fustinian to the End of the Eastern Roman Empire (527-I453)]. Beck, Munich. Second edition, translation by D. Jenkins and D. Bachrach, University of Notre Dame, Notre Dame, Indiana. Available online at http://www.byzantine.nd.edu/ krumbacher.htm [Accessed i3 February 2005].

Eyben, E. I980-8I. Family planning in Greco-Roman antiquity. Ancient Society I I/I 2, 60-7. Falkner, T. M. 1995. The Poetics of Old Age in Greek Epic, Lyric and Tragedy. University of Oklahoma Press, Norman, Oklahoma.

Finley, M. I984. The elderly in classical antiquity. Ageing \& Society, 4, 3, 39I-408.

Garland, R. 199o. The Greek Way of Life. Cornell University Press, Ithaca, New York.

Gibbon, E. I896. The History of the Decline and Fall of the Roman Empire. Editor: Bury, J. B., Volume 3, Methuen, London (First published i78I).

Grigg, R. I987. Byzantine credulity as an impediment to antiquarianism. Gesta, 26, 3-9.

Horden, P. 2005. The earliest hospitals in Byzantium, Western Europe and Islam. Fournal of Interdisciplinary History, 35, 3, 36I-89.

Hughes, P. I979. A History of the Church. Three volumes, Sheed and Ward, London.

Jenkins, R. J. H. I967. Social life in the Byzantine Empire. In Hussey, J. M. (ed.), The Cambridge Medieval History: Volume IV, The Byzantine Empire: Part II Government, Church and Civilisation. Cambridge University Press, Cambridge, 79-104.

Johnson, P. and Thane, P. (eds) 1998. Old Age from Antiquity to Post-Modernity. Routledge, London.

Kazhdan, A. I993. State, feudal and private economy in Byzantium. Dumbarton Oaks Papers, 47, 83-I00.

Kazhdan, A. P. 1998. Women at home. Dumbarton Oaks Papers, 52, I-17.

Kazhdan, A. and Constable, G. I982. People and Power in Byzantium: An Introduction to Modern Byzantine Studies. Dumbarton Oaks Center for Byzantine Studies, Trustees for Harvard University, Washington DC.

Kazhdan, A. P. and Epstein, A. W. 1990. Change in Byzantine Culture in the Eleventh and Twelfth Centuries. University of California Press, Berkeley, California.

Laiou-Thomadakis, A. E. 1977. Peasant Society in the Late Byzantine Empire: A Social and Demographic Study. Princeton, New Jersey.

Laiou, A. E. 2002. The human resources. In Laiou, A. E. (ed.), The Economic History of Byzantium: From the Seventh Through the Fifteenth Century. Dumbarton Oaks Research Library and Collection, Washington DC, 47-55.

Lascaratos, J. and Poulacou-Rebelacou, E. 200o. The roots of geriatric medicine: care of the aged in Byzantine times (324-I453 AD). Gerontology, 46, I, 2-6. 
Lascaratos, J., Kalantzis, G. and Poulacou-Rebelacou, E. 2004. Nursing homes for the old (gerocomeia) in Byzantium (324-I453 AD). Gerontology, 50, 2, II3-7.

Lascaratos, J., Tsiamis, C., Lascaratos, G. and Stavrianeas, G. 2004. The roots of cosmetic medicine: hair cosmetics in Byzantine times (AD 324-I453). International fournal of Dermatology, 43, 5, 397-40I.

Lassen, E. M. I997. The Roman family: ideal and metaphor. In Moxne, H. (ed.), Constructing Early Christian Families. Routledge, London, I03-20.

Lefort, J. I993. Rural economy and social relations in the countryside. Dumbarton Oaks Papers, 47, IOI-I3.

Litavrin, G. G. 1990. Family relations and family law in the Byzantine countryside of the eleventh century: an analysis of the prakitkon of 1073. Dumbarton Oaks Papers, 44, I87-93.

Maguire, H. i989. Style and ideology in Byzantine imperial art. Gesta, 28, 217-31.

Mango, C. 1994. Byzantium: The Empire of the New Rome. Phoenix, London.

Marx, K. I965. The German Ideology. Lawrence and Wishart, London.

MacCormack, S. 1997. Sin, citizenship and the salvation of souls: the impact of Christian priorities on late Roman and post-Roman society. Fournal of Comparative Research in Society and History, 39, 4, 644-73.

Miller, T. S. I984. Byzantine hospitals. Dumbarton Oaks Papers, 38, 53-63.

Minois, G. 1989. History of Old Age. Polity, Cambridge.

Morris, R. 1976 . The powerful and the poor in Ioth century Byzantium: law and reality. Past and Present, 73: 3-27.

Morrisson, C. and Sodini, J.-P. 2002. The sixth century economy. In Laiou, A. E. (ed.), The Economic History of Byzantium. Dumbarton Oaks Research Library and Collection, Washington DC, I7 I-220.

Neville, L. 2004. Authority in Byzantine Provincial Society, 950-IIoo. Cambridge University Press, Cambridge.

Norwich, J. J. 1998. A Short History of Byzantium. Penguin, Harmondsworth, Middlesex.

Ostrogorsky, G. I968. History of the Byzantine State. Second edition, Translation J. Hussey, Oxford University Press, Oxford.

Parkin, T. G. 2003. Old Age in the Roman World: A Cultural and Social History. Johns Hopkins University Press, Baltimore, Maryland.

Patlagean, E. I977. Pauvreté économique et pauvreté sociale à Byzance, $4^{e}-7^{e}$ siècles [Economic and Social Poverty in Byzantium: Fourth to Seventh Centuries]. Mouton, Paris.

Psellus, M. ig66. Fourteen Byzantine Rulers. Translator E.R.A. Sewter, Penguin, Harmondsworth, Middlesex.

Richardson, B. E. I969. Old Age Amongst the Ancient Greeks. Greenwood, New York.

Rigby, S. A. 1998. Marxism and History: A Critical Introduction. Manchester University Press, Manchester.

Runciman, S. 2003. The Byzantine Theocracy. Cambridge University Press, Cambridge.

Runciman, W. G. 2004. The diffusion of Christianity in the third century AD as a case study in the theory of cultural selection. Archives of European Sociology, 65, 3-2I.

Scheltema, H. J. ig67. Byzantine law. In Hussey, J. M. (ed.), The Cambridge Medieval History: Volume IV, The Byzantine Empire: Part II Government, Church and Civilisation. Cambridge University Press, Cambridge, 55-78.

Stephenson, P. 2004. Byzantium transformed, circa 950-1200. Medieval Encounters, Io, I85-2 I0.

Szucs, J. I988. Three historical regions of Europe. In Keane, J. (ed.), Civil Society and the State. Verso, London, 29I-332.

Talbot, A.-M. M. 1984. Old age in Byzantium. Byzantinische Zeitschrift, 77, $267-78$.

Talbot, A.-M. 1990. The Byzantine family and the monastery. Dumbarton Oaks Papers, 44, II9-29. 


\section{Chris Gilleard}

Thane, P. (ed.) 2005. The Long History of Old Age. Thames and Hudson, London.

Tredgold, W. 200r. A Concise History of Byzantium. Palgrave, Basingstoke, Hampshire.

Wickham, C. 1984. The other transition: from the ancient world to feudalism. Past and Present, го3, 3-36.

Accepted I4 February 2007

Address for correspondence:

Chris Gilleard, Centre for Behavioural and Social Sciences in Medicine, University College London, Wolfson Building, Riding House Street, London $\mathrm{W}_{\mathrm{IN}}$ 8AA.

E-mail: C.Gilleard@aol.com 